\title{
Mathematical Representation Ability of Senior High School Students: An Evaluation from Students' Mathematical Disposition
}

\author{
Aflich Yusnita Fitrianna ${ }^{1)}$, Sofie Dinia ${ }^{1)}$, Mayasari ${ }^{1)}$, Astri Yuliani Nurhafifah ${ }^{1)}$ \\ ${ }^{1)}$ Department of Mathematics Education, IKIP Siliwangi \\ Corresponding author: kinarian2017@gmail.com
}

\begin{abstract}
The purpose of this study is to describe students' ability in solving mathematical representation problems evaluated from mathematical disposition. The subjects are three students of $10^{\text {th }}$ grade of public senior high school (PSHS) in Padalarang, West Java, Indonesia. They were selected from 35 students with high, medium, and low mathematical disposition ability. The results of the study showed that almost all of the students able to use visual representation to solve mathematical problems, and create mathematical models and solve problems by involving mathematical expressions. In contrast, most of students could not fulfill two indicators of the mathematical representation ability, i.e. creating the sketch of geometric patterns and making the mathematical model based on the situation and data given.
\end{abstract}

Keywords: mathematical representation, mathematical disposition, misconception

\section{Introduction}

The low achievement of Indonesian students has been a classic issue in education. The Indonesian students achievement in Mathematics are at low position compared with the other countries (OECD, 2014; Provasnik et al., 2012). The mathematical representation and disposition ability are two important parameters in recent mathematics education in Indonesia. Representation ability is a fundamental ability to be developed and possessed by students. Dahlan (2011) suggested representation ability as the foundation that allows a student to understand and utilize mathematical ideas appropriately. Such representations include drawings (sketch), diagrams, graphs and symbols to help students communicate their mathematical ideas. However, in fact, students' mathematical representation ability is relatively poor. Dewi and Sopiany (2017) reported a finding that students have low representation ability to make problem situations based on the provided data or representations. They tend to have difficulty in making inquiries in accordance with the description of data. They also merely focusing on the figure without any attention on the available information. In addition, Suryowati (2015) revealed that students have not been able to interpret real-world problems into mathematical representation problems.

Kenney in Aisha (2012) claimed that the representation in the forms of words, graphs, tables, and statements is a learning approach that provides an opportunity to present students' ideas in learning mathematical concepts without any restrictions. Furthermore, Lesh, Post and Behr in Hwang et al., (2009) divided mathematical representations into five categories; real life experiences, concrete model, arithmetic symbols, oral or verbal language, and diagrams or graphs. Among these five categories, the last three representations reflect the more abstract and higher level in the 
representation of mathematical problem solving. Similarly with the former notions, Kusumah (2016) asserted representation as how the student re-interpret a problem into a simple form based on with their understanding and communicate a solution obtained through external representations that can be verbal, symbolic, or visual. Meanwhile, the internal representation is how students develop their knowledge to work their mind.

In this research, the resarcher formulate five indicators of the mathematical representation ability; 1) use visual representation to solve a problem; 2) present data/information from a representation into diagrams, graphs or tables and solve a problem using written words or texts; 3) develop equations or mathematical models of the provided representations and solve a problem by involving mathematical expressions; 4) draws geometric patterns, to write down the steps of solving mathematical problems with word and solve problems with mathematical expressions; and 5) create a problem situation based on the provided data or representation.

Learning mathematics is not solely intended to develop cognitive dimension. Fheldaus (2014) argued that learning that entails and develop the affective dimension of students is a key component for students' achievement in learning mathematics. The affective dimension is the other term of Mathematical Disposition. Sumarmo (2010) defined that disposition as the student's strong willingness, consciousness, and dedication to learn and carry out various mathematical activities. Wardanny (2017) explained several indicators of mathematical disposition, including confidence, expectation and metacognition, tenacity and seriousness in learning mathematics, persistence in dealing with and solving problems, high curiosity, and ability to share opinions/information with others. These indicators imply the mathematical disposition as a major factor in determining the students' success in learning mathematics.

This study was conducted to investigate the mathematical representation ability evaluated from the mathematical disposition related to sudents' difficulties. Therefore, the aim of this study was to describe the students' difficulties in solving mathematical representation problems based on their mathematical disposition.

\section{Research Methods}

This study employed a qualitative descriptive method. The subjects of this study were 35 students of $10^{\text {th }}$ grade of public senior high school (PSHS) in Padalarang, West Java. The instruments used to collect the data were questionnaires and test. The questionnaire was used to determine the mathematical disposition of students in the mathematics learning process (Apendix A). While the test was used to obtain the students' ability in solving mathematical representation problems. There were five problems which was represent each indicator of mathematical representation (Apendix B). The test results were analyzed using qualitative analysis in accordance with the indicators of mathematical representation ability.

The students' mathematical disposition refer to the questionnaire instrument of mathematical disposition ability from Nuraida (2017) that in the form of Likert's scale of Strongly Agree (SA), Agree (A), Disagree (D) and Strongly Disagree (SD). Subsequently, the scale was converted into quantitative data with the criteria in Table 1.

Table 1. The Criteria of Students' Mathematical Disposition

\begin{tabular}{ll}
\hline \multicolumn{1}{c}{ Score } & Category \\
\hline Score $<58.5$ & Low $(\mathrm{L})$ \\
$58.5 \leq$ score $\leq 65.5$ & Moderate $(\mathrm{M})$ \\
score $>65.5$ & High $(\mathrm{H})$ \\
\hline
\end{tabular}


Based on the results of the questionnaire, 35 students were grouped into three categories as shown in Table 3 . Then, each group were selected one student to interview.

Table 2. Category of Students' Mathematical Disposition Ability

\begin{tabular}{cc}
\hline Category & Number of Students \\
\hline High & 10 \\
Moderate & 13 \\
Low & 12 \\
\hline
\end{tabular}

\section{Results and Discussion}

The students' test results on the mathematical representation problems based on mathematical disposition ability was presented in Table 3 .

Table 3. The Number of Students' Correct and Incorrect Answers Based on Mathematical Disposition Ability

\begin{tabular}{ccccccc}
\hline $\begin{array}{c}\text { Question } \\
\text { Number }\end{array}$ & \multicolumn{2}{c}{ High (H) } & \multicolumn{2}{c}{ Moderate (M) } & \multicolumn{2}{c}{ Low (L) } \\
\cline { 2 - 7 } & Correct & Incorrect & Correct & Incorrect & Correct & Incorrect \\
\hline $\mathbf{1}$ & 10 & 0 & 12 & 1 & 12 & 0 \\
2 & 8 & 2 & 7 & 6 & 1 & 11 \\
3 & 8 & 2 & 8 & 5 & 10 & 2 \\
4 & 3 & 7 & 2 & 11 & 3 & 9 \\
$\mathbf{5}$ & 3 & 7 & 4 & 9 & 1 & 11 \\
\hline
\end{tabular}

The first problem measured the first indicator of mathematical representation, which is the utilization of visual representation to solve a problem. The indicator describes the student's ability in solving the problem relating with the congruency of two-dimensional figures. All students with high and low mathematical disposition ability were able to solve the first question correctly. While, only one student with incorrect answer on the moderate mathematical disposition group. Hence, it was indicate that almost all of students have been able to recognize the congruent figures.

Furthermore, the second problem incorporates with the second indicator of mathematical representation, namely present the data/information from a representation into diagrams, graphs or tables and to answer questions using written words or texts. This indicator indicates the students' ability in solving problems about presenting data into figures and identifying problems using words. Most of students with high mathematical disposition ability were able to answer the second problem correctly. In contrast, almost all of students with low mathematical disposition ability did not able to solve the second problem appropriately. It implies that the students with low mathematical disposition have obstacles in presenting the data into figures and in solving the problem by using written words or text. Whereas in the students with moderate mathematics ability, the number of students who were able to answer correctly is almost the same as the number of students with incorrect answer.

The third problem evaluated the third indicator of mathematical representation, namely to develop mathematical equation or model and to solve problems by involving mathematical expressions. It showed the students' ability in making given mathematical equations or models and in solving problems by using mathematical expressions. Based on Table 3, most of students in high, moderate, and low mathematical disposition ability able to solve the problem correctly. It was indicate that the students have been able to 
create mathematical models and solve problems by involving mathematical expressions appropriately.

Hereinafter, the fourth problem related with the fourth indicator of mathematical representation ability, which is to draw the geometry form to clarify the problem and facilitate the solution. This indicator describes the students' ability in drawing based on the given situation. Overall, only eight students were able to draw (sketch) the geometry based on the given situation. It indicates that the students have poor ability in drawing the geometry. Furthermore, the last problem was to assess the fifth indicator of mathematical representation ability, namely to create word problem on the given situation. This indicator explain the students' ability in making questions in written words or text in accordance with the given situation. Based on the test results, the students' ability to create the word problem on the given situation as poor as to draw the geometry. Only eight students were able to make the questions in written words in accordance with the given situation.

Based on the data, most of the students have the ability on the first indicator, namely the ability to use visual representation to solve mathematical problems. They already recognize and can distinguish the congruent two-dimensional figures. This finding confirmed Apriani (2016) in which students prefer to use visual representation to make it easier to work on the problem. The students also use the drawing to clarify what is in their minds so that from the drawing students find the idea of the solution. The study of Kholiqowati, Sugiarto, Hidayah (2016) concluded that in each type of the characteristics of learners' way of thinking, learners are possible to have good category in visual representation.

Furthermore, this study also investigated the students' misconceptions on the fourth and fifth indicator of representation ability which is related to the fourth and fifth problems of mathematical representation. The data on the Table 3 showed that the students' ability in solving the fourth problem as poor as on the fifth problem. This indicates the difficulty of students in solving both problems. In other words there were misconceptions so that they were unable to solve both problems correctly.

The Figure 1 showed the answer of the student with high disposition ability in solving the fourth problem.

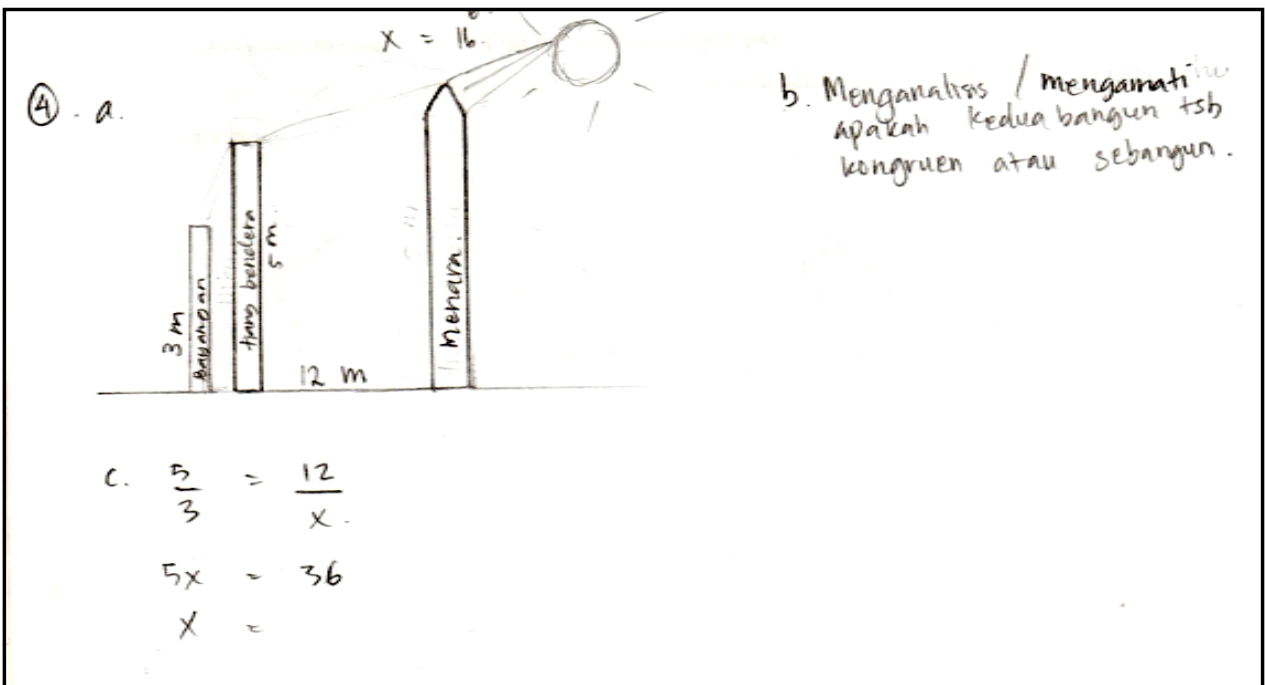

Figure 1. The answer of fourth problem from the student with high disposition ability 
Figure 1 showed that the student was unable to draw a picture (sketch) of the given situation appropriately. The sketch drawn by the student was not in accordance with the given problem situation. It illustrates that students have not been able to draw the geometry pattern to clarify and facilitate problem solving. On the next question, students were asked to write down the steps they needed to calculate the tower height. However, the answer only the solution without any description to solve the problem. On the last question of the fourth problem, the students were required to determine the height of the tower with the data that had been given. Nevertheless, the students were not able to determine the height and the precise side to perform the calculation with the concept of comparative. Moreover, the students have not been able to solve the mathematical model that have been made.

Likewise, the student with moderate and low mathematial disposition

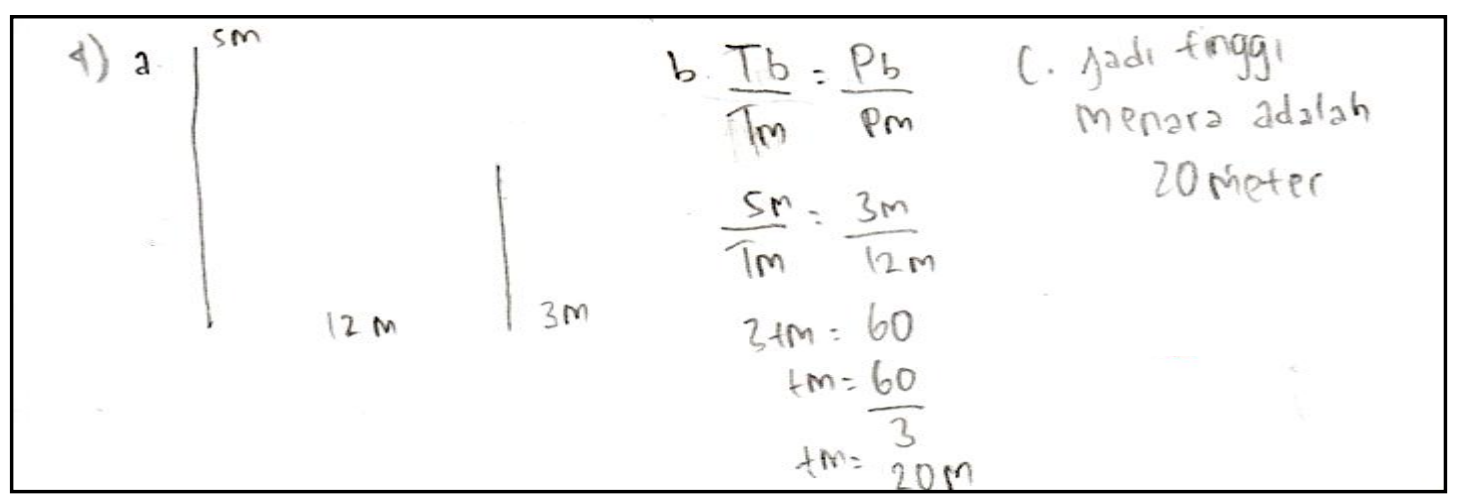

Figure 2. The answer of fourth problem from student with moderate disposition ability

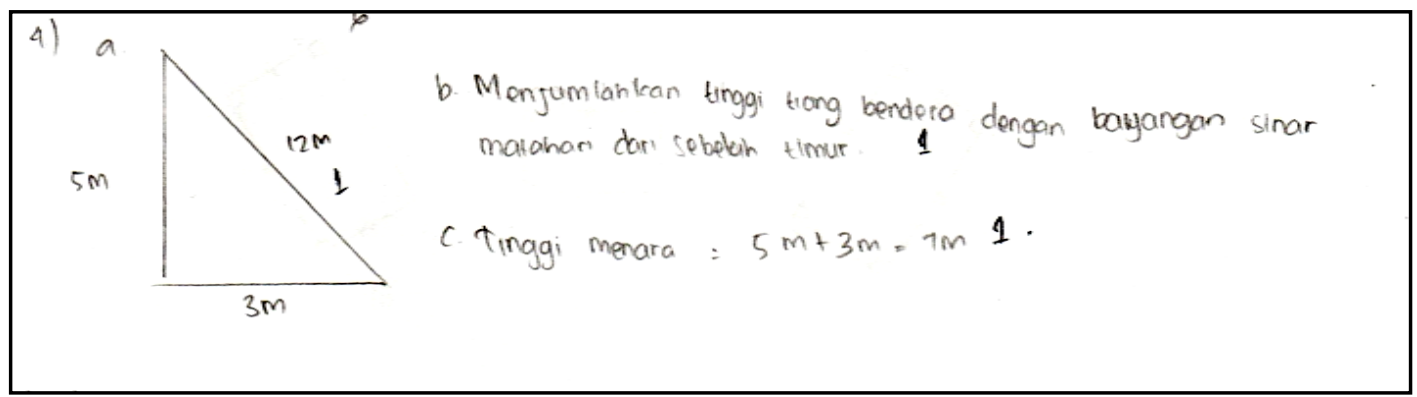

Figure 3. The answer of fourth problem from student with low disposition ability

In the Figure 2, it can be seen that the student with moderate disposition ability fail in drawing a sketch of a given situation. The sketch was not appropriate to the given problem situation. In addition, the student could not explain the procedure to determine the height of the tower. He calculate the fourth problem directly to determine the height of the tower. As a result, there was an error in determining the size and comparison of the value to the given sides. Likewise, the student with low mathematical disposition ability had not been able to sketch the given situation properly as shown in Figure 3. The student wrote down the steps to calculate the height of the tower with words although it was less appropriate. Therefore, the calculation to determine the height of the tower is not appropriate too.

Based on the students' answers, it can be concluded that students have not been able to draw a sketch of the given situation. In addition, they have not written the proper 
procedure to solve the problem. They also have difficulty to determine the pair of the corresponding sides in the calculations. Consequently, most of the students failed to represent a situation into a sketch and made misconception since they did not understand the pair of corresponding sides.

This study result confirmed Husna's findings (2015) which concluded that the students' difficulties in solving the word problem related to mathematical representation were to find keywords and understand the information in the problem, the inability of students in making mathematical models, and lack of accuracy in doing calculation. The study of Dewi and Sopiany (2017) also concluded that the misconception of students in solving the mathematical representation problem occurs on the indicator of the ability to make questions in accordance with the description or data given.

Hereinafter, the example of students answer in solving the fifth problem for high, moderate, and low mathematical disposition ability are presented in Figure 4, 5, and 6.

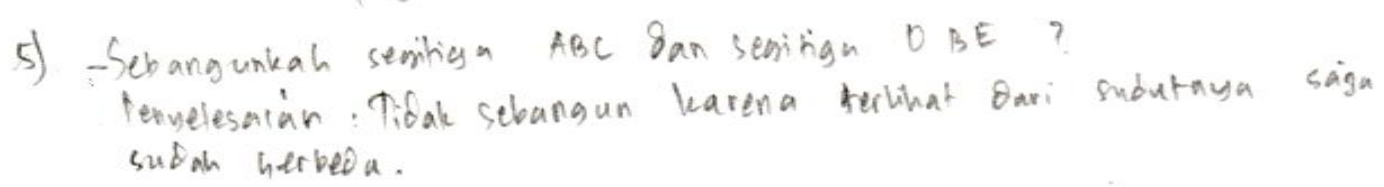

Figure 4. The answer of fifth problem from student with high disposition ability

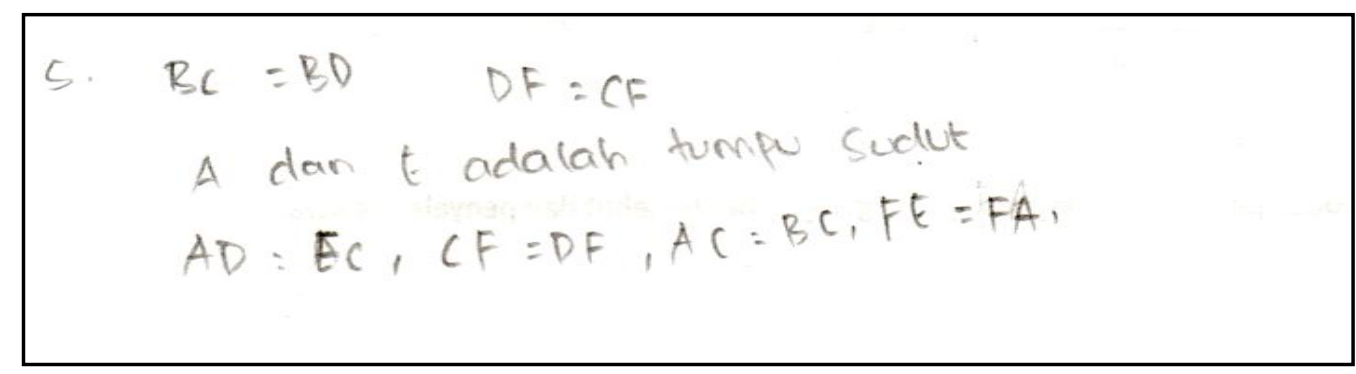

Figure 5. The answer of fifth problem from student with moderate disposition ability

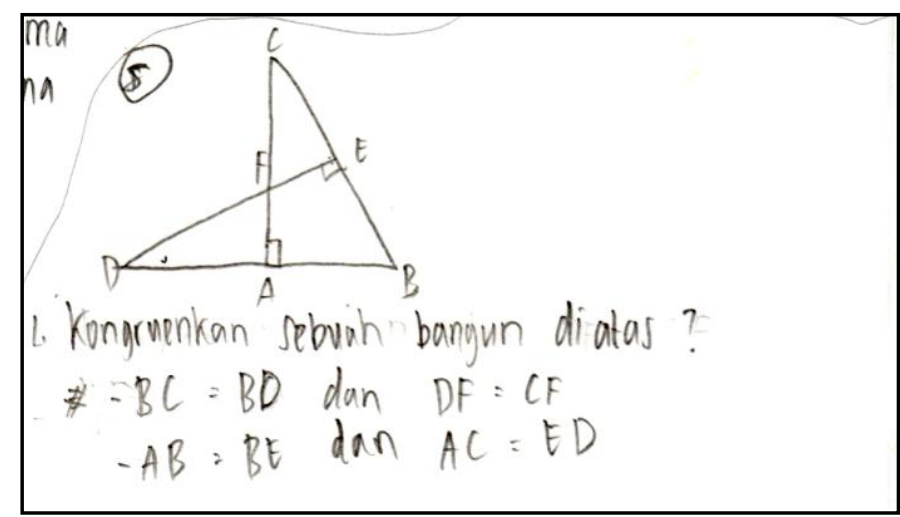

Figure 6. The answer of fifth problem from student with low disposition ability

The student with high mathematical disposition ability had not been able to create a problem situation involving congruence by using written words or texts. The answer did not suit the given problem situation, hence the answer was incorrect. Furthermore, 
the student with moderate mathematical disposition ability showed the ability to determine appropriate pair of corresponding sides although there was an incorrect assumption where the AC should correspond to the ED. The student with low mathematical disposition ability had been able to determine each pair of corresponding sides. Nevertheless, he assumed that the figures are congruent since the two figures are not congruent due to their different sizes and the angle is not necessarily the same.

Based on the answer in Fgure 6, the student provided by students at each level of mathematical disposition ability, it indicates that most of the students have not been able to arrange the words according to the given situation. In general, they have a propensity to assume the figures are congruent. Actually, there is no clue or data that indicates the two figures are congruent. They were only required to make question relating to congruence, such as the pair of corresponding sides or angles.

This study results in line with the findings of Dewi and Sopiany (2017) which stated that students relatively have low mathematical representation ability particularly on the ability to make problem situations based on given data or representation. It is difficult for students to make inquiries in accordance with given information or data. since they only focus on the figure without taking account from other information, hence the formulated problem is incorrect. In addition, Herlina, Yusmin and Nursangaji (2017) concluded that in general the ability of mathematical representation of junior high school students is included in medium category.

\section{Conclusion}

Based on the research results, the students' mathematical representation ability of junior high school can be elaborated as follows 1) most of the students with high, moderate, and low mathematical disposition have been able to achieve on the first and third indicators of mathematical representation ability, i.e. to use visual representation to solve the problem and to develop mathematical equation or model and to solve problems by involving mathematical expressions, 2) students with high mathematical disposition have been able to present data/information from a representation into diagrams, graphs or tables and solve a problem using written words or texts. In contrast, students with low mathematical disposition can not reach that indicator. Meanwhile, for students with moderate mathematical disposition are relatively balance. 3) most of the students with high, moderate, and low mathematical disposition have been lack of achievement on the fourth and fifth indicators of mathematical representation ability, i.e. to write down the steps of solving mathematical problems with word and solve problems with mathematical expressions; and create a problem situation based on the provided data or representation. It is recommended for further studies that in order to improve the students' mathematical representation ability and mathematical disposition should entail the utilization of learning model as independent variables in the subject of research that can support the learning process.

\section{Bibliography}

Aisyah, S. (2012). Meningkatkan Kemampuan Representasi dan Pemecaban Masalab Matematis Melalui Matematical Modelling dalam Model Problem Based Learning. Tesis: Universitas Pendidikan Indonesia.

Apriani, Catharina Mara. (2016). Analisis Representasi Matematis Siswa SMP dalam Memecabkan masalah matematika Kontekstual. Skripsi: Universitas Sanatha Darma Yogyakarta.

Nuraida, I. (2017). Meningkatkan Pemahaman dan Disposisi Matematik Siswa SMK dengan Menggunakan Pendekatan Pemecahan Masalah. Skripsi: STKIP Siliwangi Bandung. 
Dahlan, J. A. (2011). Materi pokok analisis kurikulum matematika. Jakarta: Universitas Terbuka.

Dewi, S.V.P., \& Sopiany, H. N. (2017). Analisis Kemampuan Representasi Matematis Siswa SMP Kelas VII Pada Penerapan Open-Ended. Prosiding Seminar Nasional Matematika dan Pendidikan Matematika (SESIOMADIKA) 2017. Hal. 680-688. ISBN: 978-602-60550-1-9

Feldhaus, C.A. (2014) . How Pre Service Elementary School Teachers' Mathematical Disposition are Influenced by School Mathematics. American international journal of contemporary research. Vol. 4, No. 6.

Herlina, Yusmin, E., \& Nursangaji, A. (2017). Kemampuan Representasi Matematis Siswa dalam Materi Fungsi di Kelas VIII SMP Bumi Khatulistiwa. Jurnal Pendidikan dan Pembelajaran, 6(10).

Husna, Asmaul. (2015). Analisis Kemampuan Representasi Matematis Siswa dalam Menyelesaiakan Soal Kontes Literasi Matematika (KLM) Pada Kelas IX SMPN 6 Banda Aceb Tabun Ajaran 2014/2015. Skripsi: Universitas Syiah Kuala. Di akses online http://etd.unsyiah.ac.id/index.php?p=show_detailevid=13883 pada tanggal 27 Februari 2018 Pukul 21:00.

Hwang, et al. (2009). Multiple Representation Skills and Creativity Effects on Mathematical Problem Solving using a Multimedia Whiteboard System. Educational Technology \& Society. Vol. 10, No. 2, Hal 191-212.

Kholiqowati, H., Sugiarto, Hidayah, I. (2016). Analisis Kemampuan Representasi Matematis Ditinjau dari Karakteristik Cara Berpikir Peserta Didik dalam Pembelajaran dengan Pendekatan Saintifik. Unnes Journal of Mathematics Education. 5(3).

Kusumah. E. C. (2016). Peningkatan Kemampuan Representasi Matematis Siswa melalui Model Means-Ends Analysis Dalam Pembelajaran Matematika. Skripsi: Universitas Pendidikan Indonesia.

OECD. (2014). PIS A 2012 in Focus: What 15-years-old know and what they can do with what they know. Retrieved from https://www.oecd.org/pisa/keyfindings/pisa-2012results-overview.pdf.

Provasnik, S., Kastberg, D., Ferraro, D., Lemanski, N., Roey, S., \& Jenkins, F. (2012). Highlights from TIMSS 2011 Mathematics and Science Achievement of U.S. Fourth-and Eighth-Grade Students in an International Context (NCES 2013-009 Revised). Washington, DC.: National Center for Education Statistics, Institut of Education Sciences, U.S. Department of Education.

Sumarmo, U. (2010). Berfikir dan Disposisi Matematik: Apa, Mengapa, dan Bagaimana dikembangkan pada Peserta Didik. http://id.scribd.com/doc/76353753/ BerfikirDanDisposisiMatematik-Utari. diakses 16 Oktober 2017.

Suryowati, E. (2015). Kesalahan siswa sekolah dasar dalam merepresentasikan pecahan pada garis bilangan. Aksioma Jurnal Pendidikan Matematika. Vol. 1, Hal 38-52

Wardanny, G. S. P. (2017). Kemampuan Pemecahan Masalah Matematis Ditinjau Dari Disposisi Matematis Siswa SMPN 3 Kediri pada Materi Lingkaran Tahun Ajaran 2016/2017. Simki-Techsain. Vol. 1, No. 8 


\section{APENDIX A \\ Mathematical Disposition Questionnarie*)}

Hint:

Choose one of the answers that best suits you by ticking $(\sqrt{ })$ on the statement:

SA : Strongly Agree

A : Agree

D : Disagree

SD : Strongly Disagree

\begin{tabular}{|c|l|l|l|l|l|}
\hline No & \multicolumn{1}{|c|}{ Activity and Opinion } & SA & A & D & SD \\
\hline 1 & $\begin{array}{l}\text { I feel confident to be able to solve complex mathematical } \\
\text { tasks }\end{array}$ & & & \\
\hline 2 & I feel hesitant to pass a math test & & & & \\
\hline 3 & I am trying to find various ways to solve the problem & & \\
\hline 4 & I refuse how to solve different problems & & & & \\
\hline 5 & I was able to study math in a long time & & & \\
\hline 6 & I am tired of doing difficult math problems & & \\
\hline 7 & $\begin{array}{l}\text { I took the initiative to propose solutions when working in } \\
\text { group }\end{array}$ & & & & \\
\hline 8 & I am waiting for my friend's solution to make learning easier & & & \\
\hline 9 & $\begin{array}{l}\text { I asked myself: Is what I'm doing correct } \\
10\end{array}$ & $\begin{array}{l}\text { I am lazy to check the answer of the problem that has been } \\
\text { done }\end{array}$ & & & \\
\hline 11 & I am able to apply mathematics in everyday life & & & \\
\hline 12 & I think that mathematics is difficult to apply in everyday life & & & & \\
\hline 13 & $\begin{array}{l}\text { By learning math, I find it easier to understand and solve the } \\
\text { problems my everyday life }\end{array}$ & & & \\
\hline 14 & $\begin{array}{l}\text { By learning math, does not make me more careful in the } \\
\text { calculations in everyday life }\end{array}$ & & & \\
\hline 15 & $\begin{array}{l}\text { When my friend has difficulty, I become the place to ask } \\
\text { questions }\end{array}$ & & & \\
\hline 16 & I dare ask the teacher if I do not understand what I learned & & & & \\
\hline 17 & $\begin{array}{l}\text { I felt scared or embarrassed when the teacher appointed me } \\
\text { to work on the board }\end{array}$ & & & \\
\hline 18 & I studied math only when faced with an exam & & & \\
\hline 19 & I created a special math-learning schedule at home on my own & & & & \\
\hline 20 & I do not really care what math test value I get & & & \\
\hline 21 & $\begin{array}{l}\text { Studying mathematics is not very useful in understanding } \\
\text { other subjects }\end{array}$ & & & & \\
\hline 22 & By studying math makes me easier in expressing opinions & & & \\
\hline
\end{tabular}

*)Adopted from Nuraida (2017) 


\section{APENDIX B}

The Mathematical Representation Test

\section{Problem 1.}

Show the pair of congruent planes in the following picture! Explain your answer!

a

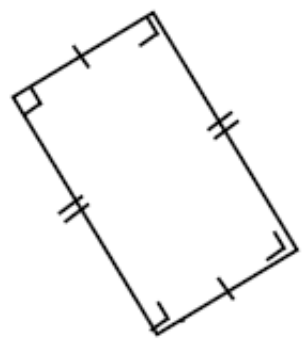

(i)

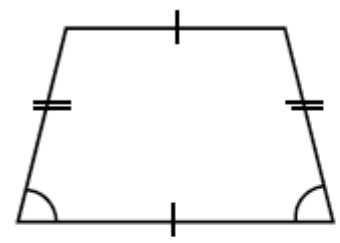

(i)

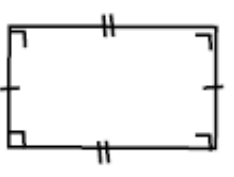

(ii)

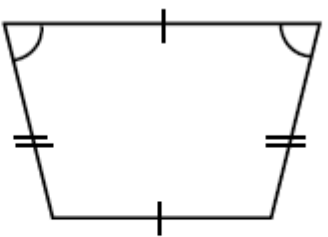

(ii)

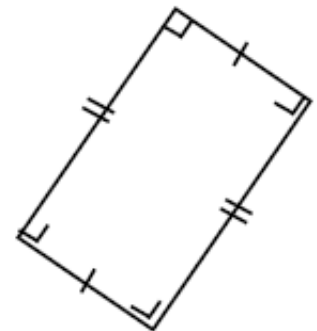

(iii)

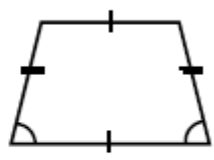

(iii)

\section{Problem 2.}

Mira has a rectangular frame with an outer edge of $30 \times 20 \mathrm{~cm}$. If the edge of the frame is a $5 \mathrm{~cm}$ wide frame,

a. Illustrate the frame in the picture

b. Identify whether the rectangle of the outer edge of the frame is similar to the inner rectangle.

\section{Problem 3.}

Given $\triangle \mathrm{ABC}$ and $\triangle \mathrm{PQR}$ as follows
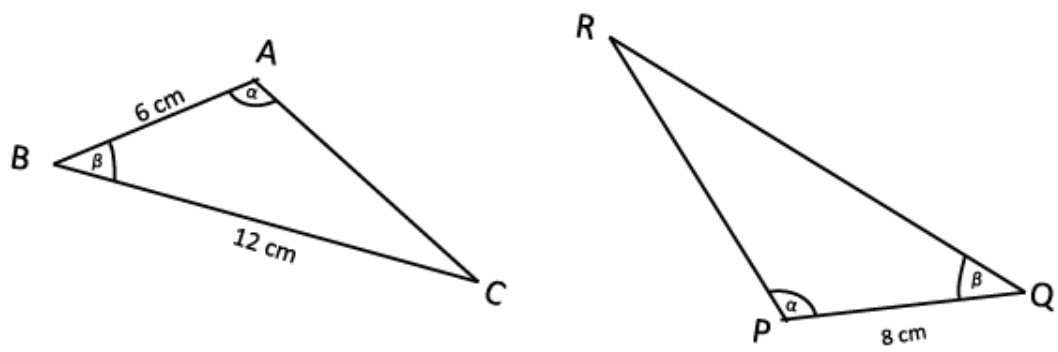

a. Is $\triangle \mathrm{ABC}$ and $\triangle \mathrm{PQR}$ congruent? If yes, specify the properties of two congruent plane

b. Determine the length of QR. 


\section{Problem 4.}

A flagpole is 5 meters tall. It is on the ground with a distance of 12 meters from a Tower. The length of the flagpole's shadow by the sunlight from the east of the Tower is 3 meters. The sunlight is about the top of the tower.

a. Draw a picture (sketch) based on the situation!

b. If you were asked to calculate the height of the tower, what measures do you need? Explain!

c. Determine the height of the tower!

(Kusumah, 2016)

\section{Problem 5.}

Look at the figure below!

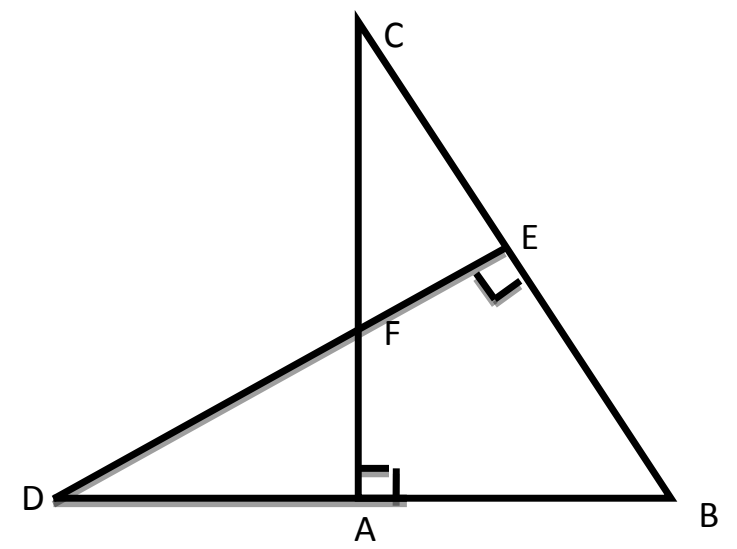

Given $\mathrm{BC}=\mathrm{BD}$ and $\mathrm{DF}=\mathrm{CF}$.

Make a question based on the figure and find the solution!

(Kusumah, 2016). 